\title{
Sobre Os pobres no cinema de Manoel de Oliveira
} Ana Isabel Soares ${ }^{1}$

Junqueira, Renata Soares (org.). 2017. Os pobres no cinema de Manoel de Oliveira. São Paulo: Todas as Musas. 268pp. ISBN 978-85-9583-004-2

Nas últimas décadas, a fortuna académica da obra de Manoel de Oliveira tem-se desenvolvido num expoente contrário ao que pareceria ditar o percurso de alguma crítica, especialmente quando tinha em conta o sucesso dos seus filmes nas salas. Característica assinalável dos estudos sobre a obra do cineasta é resultarem de investigação conduzida sobretudo em Portugal e no Brasil (com casos mais raros, mas significativos, em França e na Alemanha). Este volume, organizado por Renata Soares Junqueira (Professora da Universidade Estadual Paulista), reúne ensaios de alguns dos mais interessantes investigadores que, de um lado e do outro do Atlântico, se têm dedicado à produção oliveiriana. Acrescenta-se ao panorama crítico luso-brasileiro um texto de Guillaume Bourgois, central (até no sentido literal) para o entendimento da tese que o título do livro deixa perceber: que os pobres figurados no cinema de Manoel de Oliveira constituem não apenas o povo que Oliveira pretende revelar, mas o segmento mais ajustado para representar a nação portuguesa (cf. p. 136). Pobreza e povo são, portanto, equiparados, em todos os ensaios aqui coligidos, os quais, na sua maioria, operam análises de filmes agrupados por essa proximidade temática.

O tópico do povo - logo, da pobreza - atravessa a filmografia de Oliveira desde a obra inaugural (Douro, Faina Fluvial, de 1931) até à derradeira longa-metragem (O Gebo e a Sombra, de 2012). Seria de esperar que, depois de algumas monografias organizadas sem uma linha temática delimitadora, de um único autor ou com ensaios de proveniências distintas, surgisse uma que precisamente assumisse um eixo organizador tão destacado. Os trabalhos de Mathias Lavin (já com dez anos) ou de Thomas Brandlmeier (editado em 2010), respetivamente desenvolvidos em torno da força da palavra e dos lugares na obra oliveiriana e da relação dos filmes de Oliveira com a noção do grotesco, servem de exemplo ao que algumas teses académicas (em número cada vez mais considerável) vêm igualmente a aprofundar: modos de entendimento centrados num tema específico. Resultam ambos, assim como as teses de Maria do Rosário Lupi Bello, Guillaume Bourgois, António Preto, Nelson Araújo, ou, mais recentemente, Wiliam Pianco, da pesquisa feita por um autor único, da atenção de uma forma individual de olhar os

1 Universidade do Algarve e CIAC - Centro de Investigação em Artes e Comunicação, 8005-139 Faro, Portugal. 
filmes de Manoel de Oliveira. Distinguem-se, pelo viés do tópico congregador, de coleções monográficas como as que haviam sido publicadas por Alvaro Machado em 2005, Michelle Sales e Paulo Cunha em 2010, a mesma Renata Junqueira nesse ano e Carolin Ovehoff Ferreira em 2012 - volumes em que a totalidade da obra de Oliveira era objeto de análise, mas sem um tópico único e congregador (o que, mais do que constituir uma falha dessas obras de estudo, era revelador da urgência de dedicar aos filmes de Manoel de Oliveira uma rigorosa atenção crítica de pendor académico).

O sétimo dos catorze ensaios que compõem esta coleção que agora se edita é da autoria de Guillaume Bourgois. A sua centralidade poderá não ter sido casual; pelo contrário, encontra motivação na clareza com que o título, "Corpus Pauperum, Corpus Populi" - o corpo dos pobres, o corpo do povo - explica a tese do livro e, desse modo, lhe acrescenta coesão. Mais do que isso: insiste na maneira como quatro dos filmes do cineasta (O Pintor e a Cidade, O Pão, Acto da Primavera e $A$ Caça) constituem os exemplos maiores de como o movimento politizado do corpo (liga os quatro filmes "uma vontade política, que leva Oliveira a poderosos gestos de resistência contra as mentiras e manipulações da propaganda salazarista”, p. 124), no cinema oliveiriano, se torna espiritual.

Das restantes análises que a filmografia de Oliveira mereceu, é significativo que a maioria se tenha debruçado com preponderância sobre os filmes do começo da carreira do cineasta, sobre A Caixa - e sobre O Gebo e a Sombra. Dois dos ensaios (o de Anabela Branco de Oliveira e o de Edimara Lisboa e Mariana Copertino da Silva) coincidem no tópico de Gigantes do Douro, projeto não terminado, dedicado aos trabalhadores (os pobres) do Douro e dois outros (os de Adriana Martins e de Maria do Rosário Lupi Bello) escolhem o roubo, mote de filmes como Aniki-Bobó, A Caixa, ou O Gebo..., como eixo interpretativo, ambos se preocupando em demonstrar como o cineasta faz depender do pobre a culpa pelos furtos das narrativas e destacando o lado humanista, e mesmo humanitário de Oliveira. $O$ Gebo e a Sombra, uma das obras em torno do roubo, é tema nuclear nas abordagens de Flavia Corradin e Francisco Manuel Silveira e de Paula Mendes Coelho: no primeiro destes textos opta-se por uma leitura comparativa do filme e da peça teatral que lhe deu origem; no segundo, acentua-se também esse olhar para a adaptação da peça, a partir dum outro texto dramático, Intérieur, de Maurice Maeterlinck. Mon Cas/ O Meu Caso é o centro do ensaio de Silvana Pessôa de Oliveira, nomeadamente no que o filme revela das figurações da pobreza (que estão para além do problema da relação entre teatro e cinema, ou cinema teatral, que a obra invoca). Outros textos aqui coligidos traçam uma panorâmica mais abrangente do cinema oliveiriano, procurando, uns mais diretamente (o da própria Renata Soares Junqueira, que desenha um arco interpretativo sobre a modernidade do cinema oliveiriano; ou o de Pedro Maciel Guimarães, que abre a coleção e sugere linhas para o entendimento das formas da filmografia de Oliveira no que constituem materialização de conteúdos temáticos); outros de maneira menos 
direta (os de Fernando Cabral Martins sobre a referida cumplicidade entre cinema e teatro em Oliveira, e de Wiliam Pianco e Samuel Paiva, que entendem o filão dos filmes de viagem - ou de viagem pela História - como uma das possíveis configurações da pobreza neste cinema), entender a pobreza como fluxo temático criticamente produtivo.

Há, na descrição deste volume, dois termos definidores dos conceitos que lhe subjazem: a coleção em que se integra é a de "estudos interdisciplinares de cinema, literatura e sociedade" e o projeto de pesquisa de que resultou "propõe uma comparação de obras cinematográficas". O modo comparativo e o quadro interdisciplinar orientam, pois, a abordagem de cada ensaio e de cada autor. O objetivo comum, sublinhado desde a introdução, é o de "iluminar, valorizando-a, a dimensão política do cinema do 'esteticista' Manoel de Oliveira” (p. 6): ou seja, presidiu à coleção a vontade de resgatar de uma visão talvez apenas ou demasiadas vezes encantada com o gesto prosódico da cinematografia oliveiriana, para dela tornar mais evidente o gesto político, porventura menos frequentemente considerado. Uma das consequências mais interessantes desta procura, suspeito que inesperada para a organizadora e os autores dos ensaios, parece-me ser a clareza como surgem imbricadas a dimensão política e a religiosa. Manoel de Oliveira talvez não desdenhasse de tal conclusão. 